\title{
Recent advances in canine leptospirosis: focus on vaccine development
}

This article was published in the following Dove Press journal:

Veterinary Medicine: Research and Reports

19 June 2015

Number of times this article has been viewed

\author{
Henricus LBM (Eric) \\ Klaasen' \\ Ben Adler ${ }^{2}$ \\ 'Global Companion Animals Research \\ and Development, Merck Sharp and \\ Dohme Animal Health, Boxmeer, \\ the Netherlands; ${ }^{2}$ Department of \\ Microbiology, Monash University, \\ Clayton, VIC, Australia
}

\begin{abstract}
Leptospirosis is a global infection of humans and animals caused by pathogenic Leptospira spp. Leptospirosis is a major zoonosis, with infection acquired from wild and domestic animals. It is also a significant cause of morbidity, mortality, and economic loss in production and companion animals. Leptospirosis in dogs is prevalent worldwide and as well as a cause of canine disease, it presents a zoonotic risk to human contacts. Canine leptospirosis does not differ greatly from the syndromes seen in other animal species, with hepatic, renal, and pulmonary involvement being the main manifestations. While the pathogenesis of disease is well documented at the whole animal level, the cellular and molecular basis remains obscure. Killed, whole-cell bacterin vaccines are licensed worldwide and have not changed greatly over the past several decades. Vaccine-induced immunity is restricted to serologically related serovars and is generally short-lived, necessitating annual revaccination. The appearance of new serovars as causes of canine leptospirosis requires constant epidemiological surveillance and tailoring of vaccines to cover emerging serovars. At the present time, there is no realistic prospect of alternative, non-bacterin vaccines in the foreseeable future.
\end{abstract}

Keywords: canine leptospirosis, vaccines, diagnosis, epidemiology, pathogenesis

\section{Introduction to leptospirosis}

Leptospirosis is almost certainly the most widespread global zoonosis. It has been reported on all continents and in virtually all mammalian species examined. ${ }^{1}$ Leptospirosis arises from infection with one of the more than 230 serovars belonging to one of at least ten pathogenic species of the Leptospira genus. ${ }^{2}$ As well being a serious human infection with upward of one million severe cases annually, leptospirosis is a major cause of disease in production and companion animals such as dogs, cattle, swine, horses, deer, and probably sheep. ${ }^{3}$ Leptospirosis is a systemic disease, characterized by fever, renal and hepatic insufficiency, pulmonary manifestations, and reproductive failure. In cattle and pigs, signs of leptospirosis include reproductive failure, abortion, weak piglets or calves, and agalactia. A commonly seen chronic manifestation of leptospirosis in horses presents as recurrent uveitis. ${ }^{4}$ Typical signs of leptospirosis in dogs may include fever, jaundice, vomiting, diarrhea, intravascular disseminated coagulation, uremia caused by renal failure, hemorrhages, and death. ${ }^{3,5}$ Animals that have either recovered from acute infection or have acquired inapparent infection may then go on to become asymptomatic renal carriers for extended periods and shed infectious leptospires into the environment. Susceptible animals can then acquire the infection by either direct or indirect contact with the urine or tissues of infected animals. Other species such as rats, mice, and other rodents may serve as 
reservoirs for their host-adapted serovars, such as Copenhageni in rats and Arborea in mice. They usually do not show signs of infection, but can harbor leptospires in their kidneys for the life of the animal, thereby constituting an important source of infection for other animals or humans. While most human cases of leptospirosis are contracted from farm animals or rodents, the potential of infection from dogs should always be borne in mind; ${ }^{5-9}$ in particular, vaccinated and/ or treated dogs may continue to excrete leptospires in their urine, constituting a human infection risk. For more detailed descriptions of the biology and taxonomy of Leptospira, the reader is referred to the appropriate chapter(s) in Leptospira and leptospirosis. ${ }^{10}$

\section{Pathogenesis of leptospirosis: the basics}

At the level of the whole animal, leptospirosis in dogs does not differ from syndromes seen in other animal species. Leptospires enter via mucosal membranes or damaged skin and spread hematogenously throughout the body during a febrile, bacteremic phase, which may last up to several days. When numbers of leptospires in various tissues reach a critical level, characteristic signs appear, such as pulmonary hemorrhage, jaundice due to liver damage, and nephritis due to kidney damage. In general, the appearance of circulating antibodies results in the clearance of leptospires by opsonophagocytosis and/or complement-mediated killing; recovery is usually complete as long as irreversible organ damage has not occurred. The exception to this clearance occurs in the proximal renal tubules, in which leptospires may persist for extended periods of time and can be shed, continuously or intermittently, sometimes for the life of the animal. ${ }^{3}$

At the molecular and cellular level, the picture is far less clear. ${ }^{11}$ It would appear to be a sine qua non that leptospires must adhere to host tissues in order to initiate infection. Indeed, a large range of leptospiral proteins has been shown to interact with a large number of host components. ${ }^{12}$ Some proteins appear to associate with multiple host proteins; for example, the lipoprotein LipL32 was shown to interact with laminin, fibronectin, and several collagens. ${ }^{13}$ The reverse is also true, with some host proteins apparently binding a multitude of leptospiral proteins; at least 20 leptospiral proteins have been reported to interact with laminin. ${ }^{11}$ In almost all cases, the studies involved recombinant leptospiral proteins, usually expressed in Escherichia coli. ${ }^{12}$ While these in vitro studies are clearly real, a caveat should be considered when assessing the biological significance of these reported interactions. Even taking into account the high functional redundancy within pathogenic Leptospira spp., ${ }^{14}$ is it really the case that leptospires possess more than 20 specific, laminin-binding proteins? Genetic studies confirming the absolute requirement or even relevance of these putative adhesins are not yet available. In fact, defined lipL32 and $\operatorname{lig} B$ mutants retained virulence and host component binding capacity. ${ }^{15,16}$

The availability of genome sequences and the development of transposon and directed mutagenesis systems have allowed the identification of a small number of defined virulence factors; these include lipopolysaccharide (LPS), motility, heme oxygenase, catalase, collagenase, the stress proteins $\mathrm{ClpB}$ and $\mathrm{HtpG}$, the cell entry protein Mce, and the ApoA1-interacting protein LruA. For a detailed description of these factors the reader is referred to Murray ${ }^{11}$ and Adler, ${ }^{12}$ where the original references may also be found. Comparative genomic analysis has indicated that genes of unknown function are highly overrepresented in the subset of genes unique to pathogenic Leptospira spp. Likewise, transcriptomic analyses have found that the majority of genes differentially regulated when leptospires were grown under simulated in vivo conditions were genes of unknown, or poorly defined, function. ${ }^{14,17}$ These findings are consistent with the notion that the Leptospira genus possesses unique virulence factors not found in other bacterial species.

\section{Canine leptospirosis: epidemiology and clinical characteristics}

The clinical signs of leptospirosis in humans and animals, including dogs, are mostly vague and always non-specific. Therefore, in practice, laboratory tests are needed to achieve a definitive diagnosis. Since isolation of the Leptospira spp. bacteria requires specific growth media and skills, and because PCR testing is not yet a routine test, the definitive diagnosis is mostly based on the microscopic agglutination test (MAT; see the "Laboratory diagnosis" section), which is the reference method for serological diagnosis of leptospirosis. ${ }^{18}$ As a consequence, most of the information relating to canine leptospirosis worldwide is based on seroepidemiological studies performed using the MAT. However, direct comparisons between different studies are complicated by the variability in cut-off MAT titers used, ranging from 10 to 800 . As is generally applied to large human populations, a low titer would be appropriate in a population in which exposure to leptospirosis is uncommon, but if exposure is frequent, as in most tropical countries, a higher cut-off titer is necessary. ${ }^{19}$ Therefore, part of the observed variation between studies in cut-off MAT titers may be attributed to 
the presumed level of exposure in the geographic region of the dogs studied. In addition, within their studies, some investigators used two different cut-off titers: a higher titer (eg, 800) for vaccine serovars and a lower titer (eg, 100) for non-vaccine serovars. As explained by Ellis et al, ${ }^{20}$ the leptospirosis literature has been bedeviled by the question of usage for arbitrary, "significant titers". They emphasized the high risk of errors in interpretation of results against arbitrary cut-off MAT titers in sero-epidemiological studies, most commonly greater than or equal to 100 , when conclusions based solely on MAT titers are drawn with regard to (sub)acute versus chronic infections, infection titers versus vaccineinduced titers, and the identity of the infecting serogroup. The identity of the infecting serogroup may be erroneous in the case of paradoxical reactions in acute phase sera. Provided that the caveats of this assay and the interpretation thereof are taken into account, sero-epidemiological studies can roughly indicate the prevalence of leptospirosis and which serogroups (not serovars ${ }^{21}$ ) of Leptospira spp. are predominant in dogs in a certain geographical area.

Table 1 gives an overview of data on seroprevalence and predominating serogroups from peer-reviewed scientific papers of sero-epidemiological studies in dogs worldwide published in the period 1973-2014. Apart from the caveats described above, the large variety between the published studies in sample size, type of dog population studied, and the number of MAT antigens (serovars) used makes it difficult to draw conclusions. The seroprevalence in randomly sampled groups of privately owned or stray dogs is an indicator of the spread of, and exposure to, Leptospira spp. bacteria in these dog populations. The variation in seroprevalence in this category of dogs, even after removal of "low MAT titers possibly induced by vaccine serovars", appears to be strikingly large: Europe, $13 \%-57 \%$; North America, 6\%-38\%; South and Central America and the Caribbean, 7\%-62\%; Asia and the South Pacific, 7\%-46\%; and Africa and the Middle East, 5\%-27\%. Seroprevalence in ten studies was lower than or equal to $15 \%$ (Table 1 ). In seven of these ten studies, at least eleven serovars representing eleven serogroups were used for the MAT, suggesting that most of the low seroprevalences were not due to missing serovars in the MAT. However, the use of only single-serum samples in most studies and the large variation in MAT cut-off titers (20-400 in healthy dogs and 100-3,200 in dogs with acute leptospirosis) are two factors that undoubtedly contribute to the large variation in seropositivity. Despite these limitations and confounding factors, it can be concluded from the reviewed studies that canine leptospirosis is an important infectious and zoonotic disease in dogs worldwide, with an increasing prevalence of seropositive dogs in time as reported in publications from various countries, including Canada, ${ }^{22}$ USA, ${ }^{23}$ Switzerland, ${ }^{24}$ and the Netherlands (EM Broens, personal communication, 2015).

As explained earlier in this section, assessment of the predominant infecting serogroups based on only serological tests is unreliable. In the reviewed studies (Table 1), very few serological data were generated with paired serum samples, and high MAT titers in acute sera from patients are unreliable indicators of the infecting serogroup, therefore, the serological results on serogroups in these studies must be interpreted with caution. However, when in a certain region the same serogroup patterns based on representative numbers of dogs are observed repeatedly and are complemented with results of identification of the infecting serovar(s) isolated from clinical cases, assessment of the predominant serovars or serogroups is more reliable.

Table 2 provides an overview of the large variety of clinical pictures and courses of leptospiral infections in dogs. The clinical presentation varies from subclinical disease (probably the majority of cases) and minimal clinical signs to severe renal, hepatic, or pulmonary disease, sometimes with intestinal complications. Whereas formerly it was considered that distinct clinical syndromes were associated with specific serogroups, more intense study over the past 30 years has refuted this hypothesis. ${ }^{18}$ Apart from the poor ability of the MAT to predict the infecting serogroup, variations in the host's immune response and possibly lateral transfer of virulence factors between serovars are other main determinants for the type and severity of clinical disease. Lateral gene transfer has not been demonstrated experimentally in Leptospira spp., but appears likely given the high degree of plasticity in leptospiral genomes. In the early years, there was a reported predominance of the classical syndromes: severe hepatic failure and acute renal insufficiency, which were thought to be caused mainly by strains of serogroups Icterohaemorrhagiae and Canicola, respectively. It is unclear whether the introduction in the 1960s in USA and Europe of bivalent vaccines directed against these two serogroups is the main cause of the observed shift in serogroup prevalence in USA and Europe, with serogroups Grippotyphosa, Pomona, and Australis emerging in dogs. In addition, increased awareness by veterinarians and more adequate tests, and subsequently, more frequent recognition of less apparent forms of the disease in dogs may well have contributed to a higher frequency of reported cases of other serogroups and other clinical presentations. 


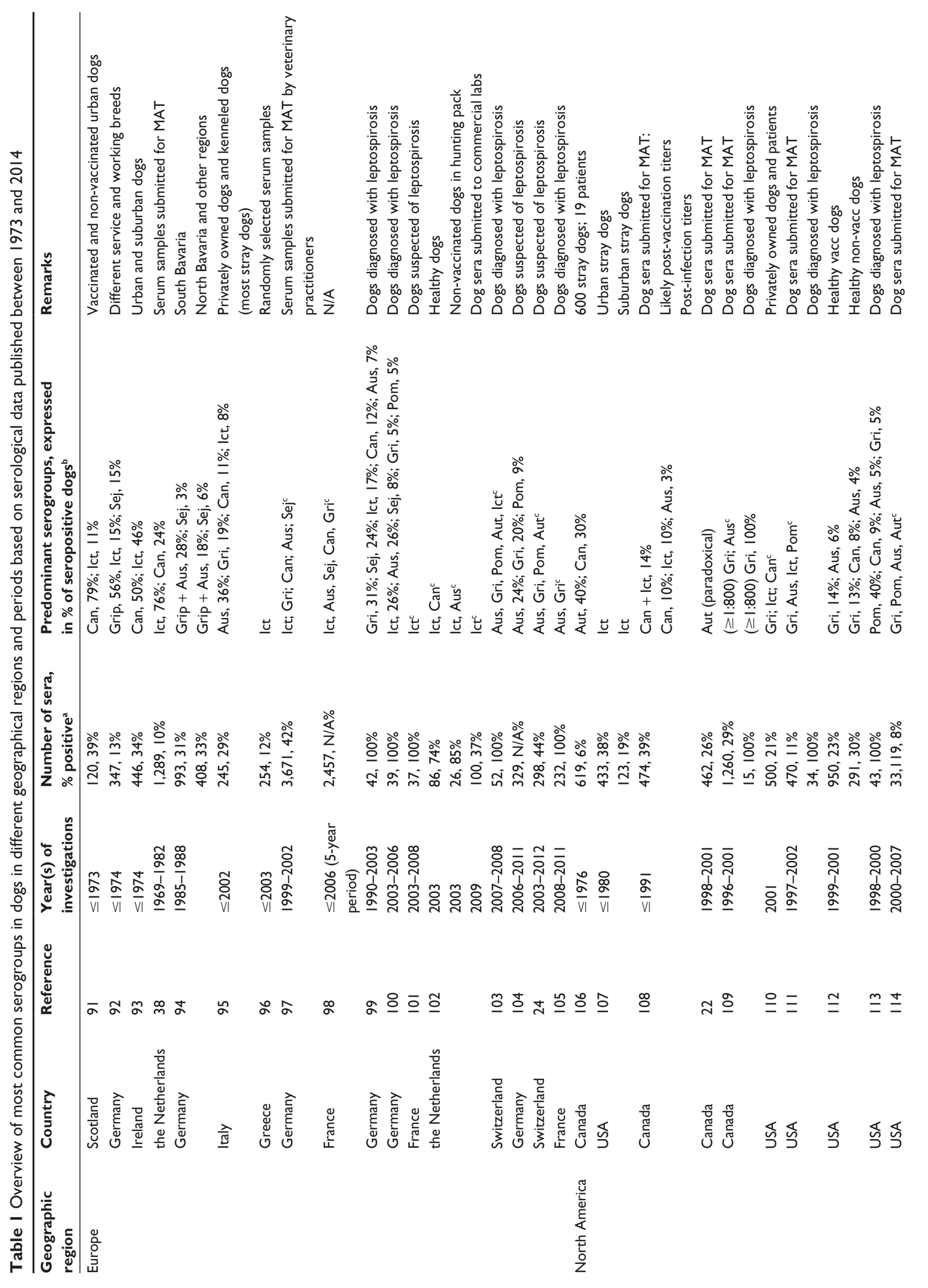




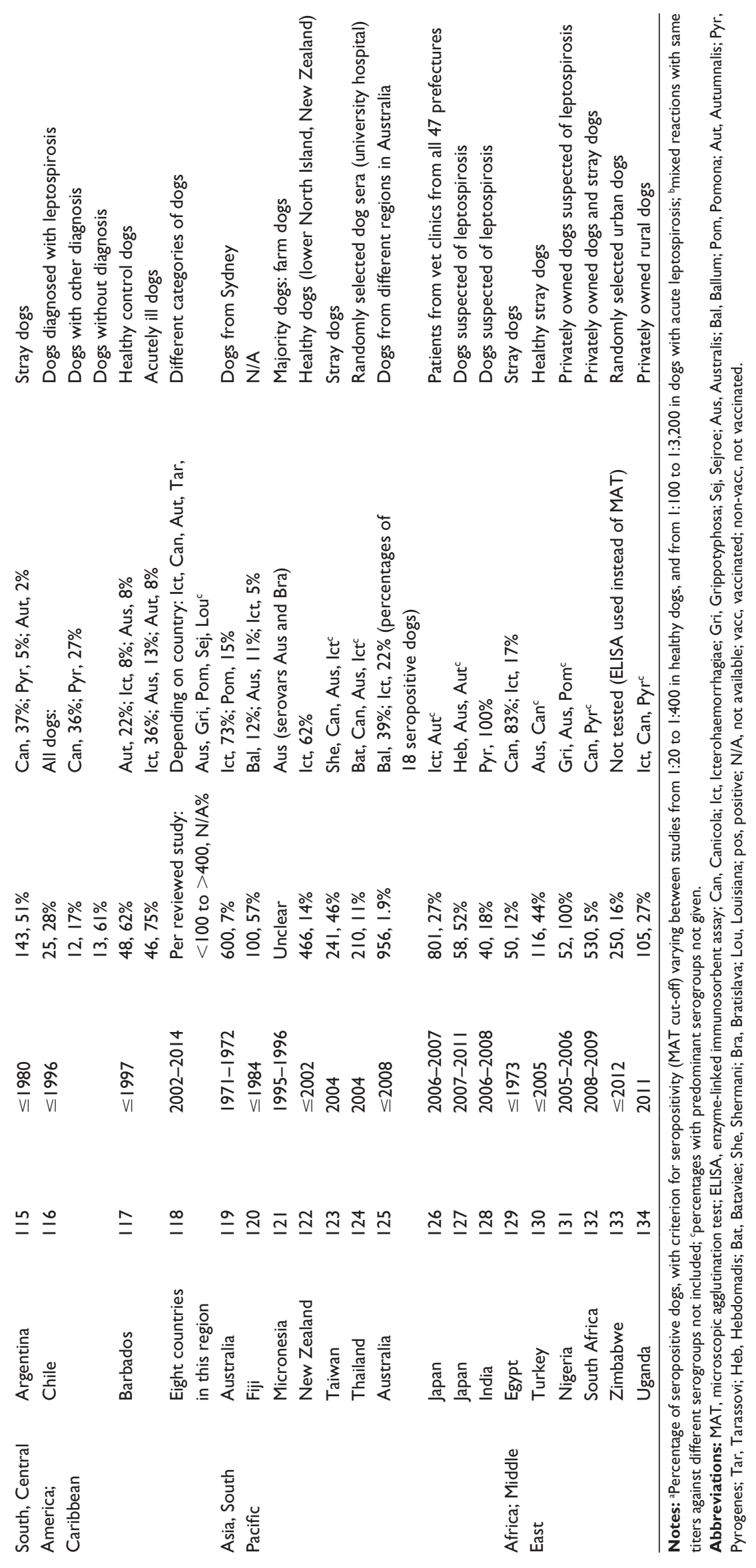


Table 2 Clinical characteristics of canine leptospirosis

\begin{tabular}{|c|c|c|c|}
\hline Clinical presentation & $\begin{array}{l}\text { Reported frequency } \\
\text { of clinical signs }\end{array}$ & Clinical signs & References \\
\hline \multirow[t]{2}{*}{$\begin{array}{l}\text { Peracute }(<24 \text { hours; rarely } \\
\text { diagnosed })^{\mathrm{a}}\end{array}$} & Most frequent & $\begin{array}{l}\text { Either sudden death or death preceded by few } \\
\text { clinical signs, eg, lethargy/depression, anorexia }\end{array}$ & $9,32,38,135-137$ \\
\hline & Less frequent & Lethargy/depression, anorexia, vomiting, diarrhea & \\
\hline \multirow[t]{2}{*}{$\begin{array}{l}\text { Acute ( } 1-2 \text { days; not often } \\
\text { diagnosed) }\end{array}$} & Most frequent & $\begin{array}{l}\text { Lethargy/depression, anorexia, vomiting, } \\
\text { muscle weakness, myalgia, death }\end{array}$ & $\begin{array}{l}9,32,33,38,39,48 \\
135-140\end{array}$ \\
\hline & Less frequent & $\begin{array}{l}\text { Fever, hypothermia, diarrhea, dehydration, PUPD, } \\
\text { jaundice, red eyes, intestinal invaginations }\end{array}$ & \\
\hline \multirow[t]{2}{*}{$\begin{array}{l}\text { Subacute ( } 2-7 \text { days; most common } \\
\text { form of diagnosed cases) }\end{array}$} & Most frequent & $\begin{array}{l}\text { Lethargy/depression, anorexia, vomiting, fever, } \\
\text { hypothermia, dehydration, polyuria and polydipsia, } \\
\text { abdominal pain on palpation, diarrhea }\end{array}$ & $\begin{array}{l}6,9,32,33,36,38,39 \\
48,135-140\end{array}$ \\
\hline & Less frequent & $\begin{array}{l}\text { Intestinal invaginations, weight loss, muscle weakness, } \\
\text { myalgia, coughing, dyspnea, jaundice, pale mucous } \\
\text { membranes, petechiae, abortion, death }\end{array}$ & \\
\hline \multirow[t]{2}{*}{$\begin{array}{l}\text { Chronic ( }>\text { I week; not often } \\
\text { diagnosed) }\end{array}$} & Most frequent & $\begin{array}{l}\text { polyuria and polydipsia, jaundice, weight loss, } \\
\text { emaciation, anterior uveitis }\end{array}$ & $6,28,36,137$ \\
\hline & Less frequent & Petechiae, hemoptysis, ascites, abortion, death & \\
\hline $\begin{array}{l}\text { None = subclinical leptospirosis } \\
\text { (probably majority of infected dogs) }\end{array}$ & Not applicable & Not applicable & 25,137 \\
\hline
\end{tabular}

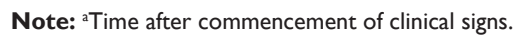

Abbreviation: PUPD, polyuria/polydipsia.

In two different studies ${ }^{25,26}$ in a group of clinically healthy laboratory beagle dogs used for research or quality control purposes, an association between subclinical infection with a serovar from serogroup Sejroe and interstitial nephritis were demonstrated. In two other studies with laboratory beagle dogs, ${ }^{27,28}$ it was strongly suggested that a leptospiral infection was the cause of the observed chronic hepatitis. These studies underline the broad spectrum of clinical symptoms of canine leptospirosis and in particular, the contrast between the reported and true prevalence of the chronic as well as subclinical forms of the disease. One of the clinical forms that has been reported more frequently in the last decade is the pulmonary form of canine leptospirosis. These investigations might partly have been triggered by the increasing number of reports of the leptospiral pulmonary hemorrhagic syndrome (LPHS) in humans. ${ }^{29-31}$ In the 1990s, there were two publications of cases of confirmed canine leptospirosis in which a small minority of the dogs showed pulmonary lesions in addition to other pathology. ${ }^{32,33}$ In other studies, ${ }^{34,35}$ pulmonary lesions were observed by radiographic examination in dogs with leptospirosis. In the study of Baumann and Fluckiger ${ }^{35}$ it was concluded that the pulmonary findings might be misinterpreted as other lung diseases. In recent studies ${ }^{36,37}$ into LPHS-like pulmonary lesions in dogs with leptospirosis, the most important necropsy finding and cause of death was severe, acute, pulmonary hemorrhages. Severe lung involvement in canine leptospirosis is more prevalent than expected based on clinical examination and causes increased case fatality rates. For a description of pathology findings in animal leptospirosis, the reader is referred to Ellis. ${ }^{3}$

\section{Clinical diagnosis}

Achieving a definitive diagnosis of leptospirosis in dogs should be of special importance to veterinary practitioners because of the zoonotic potential of the disease. ${ }^{5-8}$ In order to prevent misdiagnosis, a complete anamnesis should be carried out, particularly an assessment of potential previous exposure of the dog to sources of Leptospira spp. infection. These sources, mostly being urine from chronically infected rodents or other wild maintenance hosts, can vary greatly between geographic regions and seasons. In the past, within the group of privately owned dogs, mainly dogs in rural environments and sporting dogs were considered to be at risk. However, reports from the last decades showed that the risk of exposure to sources of Leptospira spp. infection can also be present in urban areas, particularly when dogs live in the vicinity of forests or parks or have free access to standing water. The first difficulty in making the correct diagnosis is that the clinical signs are vague and typically non-specific. ${ }^{9}$ Anorexia, lethargy, and depression are the most predominant, or the only signs. In addition, reluctance to move, abdominal pain on palpation, vomiting, polyuria/polydipsia, and diarrhea are frequently observed in cases of subacute disease. When ileus is suspected based on findings of abdominal palpation, intestinal intussusception as the underlying cause 
may be revealed using abdominal radiography. Particularly in young dogs with gastrointestinal complaints and intestinal intussusception, leptospirosis should be included in the differential diagnosis. ${ }^{38-40}$ On initial presentation, overt icterus and fever (associated with the classical icteric form of leptospirosis) are less common. Peracute or acute death (rare and uncommon, respectively) probably occur more often in young dogs. ${ }^{41} \mathrm{~A}$ definitive diagnosis of canine leptospirosis thus requires laboratory confirmation.

\section{Laboratory diagnosis}

The laboratory diagnosis of canine leptospirosis does not differ from that used in other animal species or in humans; it is beyond the scope of this review to cover in detail what is readily available elsewhere. ${ }^{3,5}$ As with most bacterial infections, culture of the infecting organism provides a definitive diagnosis. However, in the case of Leptospira spp., there are several problems with culture. Pathogenic Leptospira spp. require specialized media and are slow growing; cultures therefore require long-term incubation (up to 3 months) with weekly checking by darkfield microscopy for the presence of leptospires. Contamination may also be a problem when culturing from urine or tissues at necropsy. For details of media and culture techniques, see Cameron. ${ }^{42}$ Culture is therefore of very limited use in individual diagnosis. However, for a proper understanding of local epizootiology, it is very important that prevalent serovars are isolated and identified in order to inform the selection of serovars for inclusion in vaccine formulations.

In regions where appropriate equipment and facilities are available, polymerase chain reaction (PCR) offers an alternative to culture. There exists now an extensive literature on the use of PCR to detect leptospiral deoxyribonucleic acid (DNA), ${ }^{3,43}$ procedures are equally applicable to animal and human tissues. A range of qualitative and quantitative PCR protocols and primers has been described, mostly designed to detect all leptospires (eg, $r R N A$, secY) or genes unique to pathogenic species (eg, lipL32). Sequencing of PCR products can be used to identify the leptospiral species and to drill down further to identify so-called "genotypes". ${ }^{44}$ There is currently no PCR protocol available that will identify the infecting serovar, although with the availability of genome sequences for all serovars, this may be possible in the near future. The large number of serovars, and therefore LPS biosynthesis loci, suggests that any serovar-specific PCR would need to be tailored for local serovars, again reinforcing the necessity of sound, regional epidemiological data. As with all PCR protocols, the potential presence of inhibitors in animal tissues must be borne in mind. It is therefore very important to remember that, as for any diagnostic test, a negative PCR does not necessarily exclude the presence of leptospires, nor does a diagnosis of leptospirosis.

Antigen detection or staining methods such as WarthinStarry and other silver deposition stains, fluorescent antibodies, or immunohistochemistry techniques in general lack sensitivity, but are useful for detecting leptospires in histological sections taken by biopsy or at necropsy (Figure 1). The use of darkfield microscopy on clinical specimens (blood, urine, or other tissues) lacks sensitivity and may give rise to false positives; it is not recommended.

Serological diagnosis remains the most commonly used method, with the MAT still considered the gold standard. Because of its serovar (or at best, serogroup) specificity, good epidemiological knowledge of locally prevalent serovars is critical so that they can be included in the battery of MAT test strains. As with all serological tests, a rise in paired sera is diagnostic. A single high titer $(\geq 400)$ together with appropriate clinical signs (see Clinical Diagnosis section) is highly suggestive. As with other animal species or humans, so-called paradoxical reactions may occur in which the highest titer is not necessarily against the infecting serovar. Serological surveys are therefore unreliable indicators of locally circulating serovars, highlighting the importance of obtaining local isolates for diagnosis and vaccine usage and development. The MAT is problematic for the detection of renal carrier animals, which may have titers below the usually accepted minimal significant value, or may even be sero-negative. The presence of antibodies in the fetal circulation is an indicator of in utero infection. ${ }^{3}$

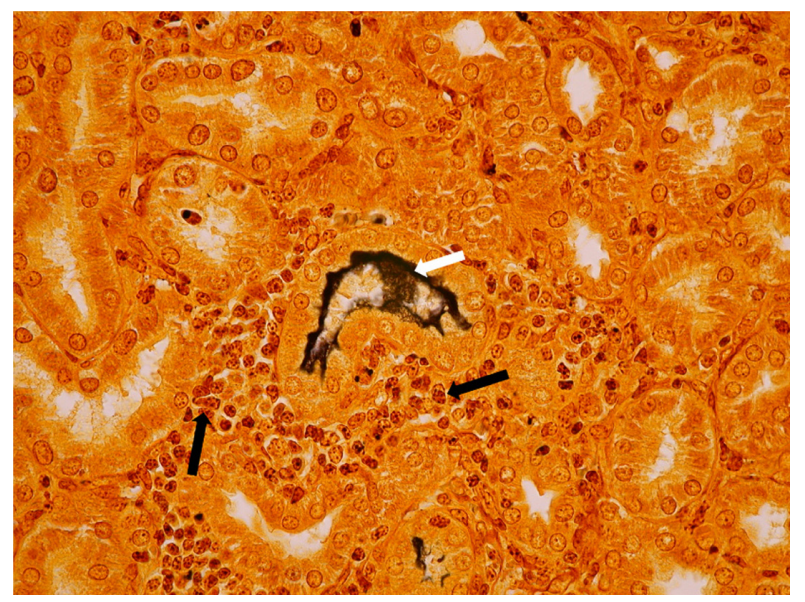

Figure I Kidney cortex, transverse section through convoluted tubules, WarthinStarry staining (magnification 400x).

Notes: Dog from non-vaccinated control group challenged with serovar Canicola. White arrow indicates massive presence of leptospires in lumen of convoluted tubule; black arrows indicate mononuclear infiltration. 
The most commonly used alternative to the MAT is the enzyme-linked immunosorbent assay (ELISA). Most published ELISA protocols use either whole cell lysates or conserved recombinant proteins (eg, LipL32, LigA) as antigens. They are therefore genus-specific and provide no information on the infecting serovar. An immunoglobulin M (IgM) ELISA may detect acute infection. ${ }^{45}$ Several commercial ELISA kits for canine diagnosis are available, although proper validation presents a problem because of the imperfect nature of the MAT in situations where paired sera are not available. Other tests such as lateral flow tests ${ }^{46}$ do not seem to have gained widespread use. Older tests such as those using complement fixation, macroscopic slide agglutination, or passive hemagglutination are not recommended.

\section{Treatment strategies}

Table 3 provides an overview of the most important treatments of peracute, acute, subacute, and chronic leptospirosis in dogs. Wohl ${ }^{47}$ described the therapeutic management of acute renal failure, which is the most prevalent clinical syndrome in canine leptospirosis, although in some European countries an increased prevalence of severe pulmonary signs has been reported. ${ }^{6}$ In (sub)acute leptospirosis, dogs have to be treated immediately with adequate antibiotics (Table 3 ) to eliminate the leptospires from the bloodstream. Aggressive supportive therapy can be life-saving for many dogs with severe anuric leptospirosis or other severe conditions. If facilities are available, hemodialysis can be life-saving in cases of severe uremia (also known as azotemia ${ }^{48}$ ). Ideally, serum biochemistry panels of dogs with acute leptospirosis should be performed every 24 hours during hospitalization to monitor renal function, liver enzyme activities, serum protein concentrations, and electrolyte and acid-base derangements. In chronic leptospirosis, antibiotics (particularly to clear leptospires from the kidneys) and supportive therapy may be needed as well. In particular, treatment of hypertension, one of the systemic complications of chronic renal failure, can be life-saving.

\section{Current perspectives on vaccines and vaccine development}

Safe and effective vaccines are one of the most important advances in veterinary medicine in the last 60 years. Licensed inactivated vaccines against canine leptospirosis have been on the market since the 1960s. In the remainder of this review, we will discuss current scientific information will be discussed with regard to efficacy of commercial, inactivated leptospirosis bacterin vaccines; the need for multivalent bacterins protective against newly emerging serovars; the risk of allergic reactions of dogs to immunization with these bacterins, particularly in small-breed dogs; growth media for bacterin vaccines; and the potential for recombinant vaccines.

\section{Efficacy of current bacterin vaccines}

Successful pioneering research on leptospirosis vaccines was performed a century ago in $\operatorname{Japan}^{49}$ with guinea pigs. In the following period, a variety of chemical and physical inactivation methods was tested to develop effective bacterins. Some of these methods, in particular formaldehyde, thiomersal, or heat inactivation, have been used for decades for the development and licensing of commercial whole cell vaccines against leptospirosis in dogs, pigs, and cattle. In the 1970s, the focus of leptospirosis vaccine research shifted toward defining the primary structural component(s) responsible for protection. ${ }^{50}$ Various groups tested the efficacy of the outer envelope of leptospires, mainly in hamsters. However, outer envelope vaccines and other inactivated acellular ${ }^{51}$ vaccines have not gained widespread support, the main reasons being lack of efficacy, lack of consistency of production, and high production costs. In this period of the 1970s, it had already been demonstrated that a higher dose of immunogen (whole cells, or outer envelope, or other cellular components) was required to protect hamsters or guinea pigs from renal infection than from death. ${ }^{52,53}$ Publications in the 1970s implicated vaccinated dogs as the source of leptospiral infections in humans and have expressed doubt as to the ability of commercial leptospirosis bacterins to protect dogs against renal infection and the carrier state. ${ }^{7,54}$ However, other studies with leptospirosis bacterins demonstrated protection from renal infection in dogs. ${ }^{54,55}$ Huhn et $\mathrm{al},{ }^{56}$ using a commercial vaccine, showed that protection from renal infection in dogs with serovar Canicola or Icterohaemorrhagiae was vaccine dose-dependent. Apart from differences in design of efficacy studies and interpretation of results, an important reason for differences in efficacy results is the immunogenicity of the bacterins used. ${ }^{57,58}$ As in veterinary and human vaccines in general, adjuvants may increase the efficacy of canine leptospirosis vaccines. Since efficacy claims of licensed vaccines, specified in the "Summary of Product Characteristics" and the leaflet of the product, ${ }^{59}$ have to comply with local regulatory requirements (eg, the 9CFR in the US and the European Pharmacopoeia in Europe), ${ }^{60}$ veterinary practitioners are informed about the ability of current commercial vaccines to protect dogs from the renal carrier state. 


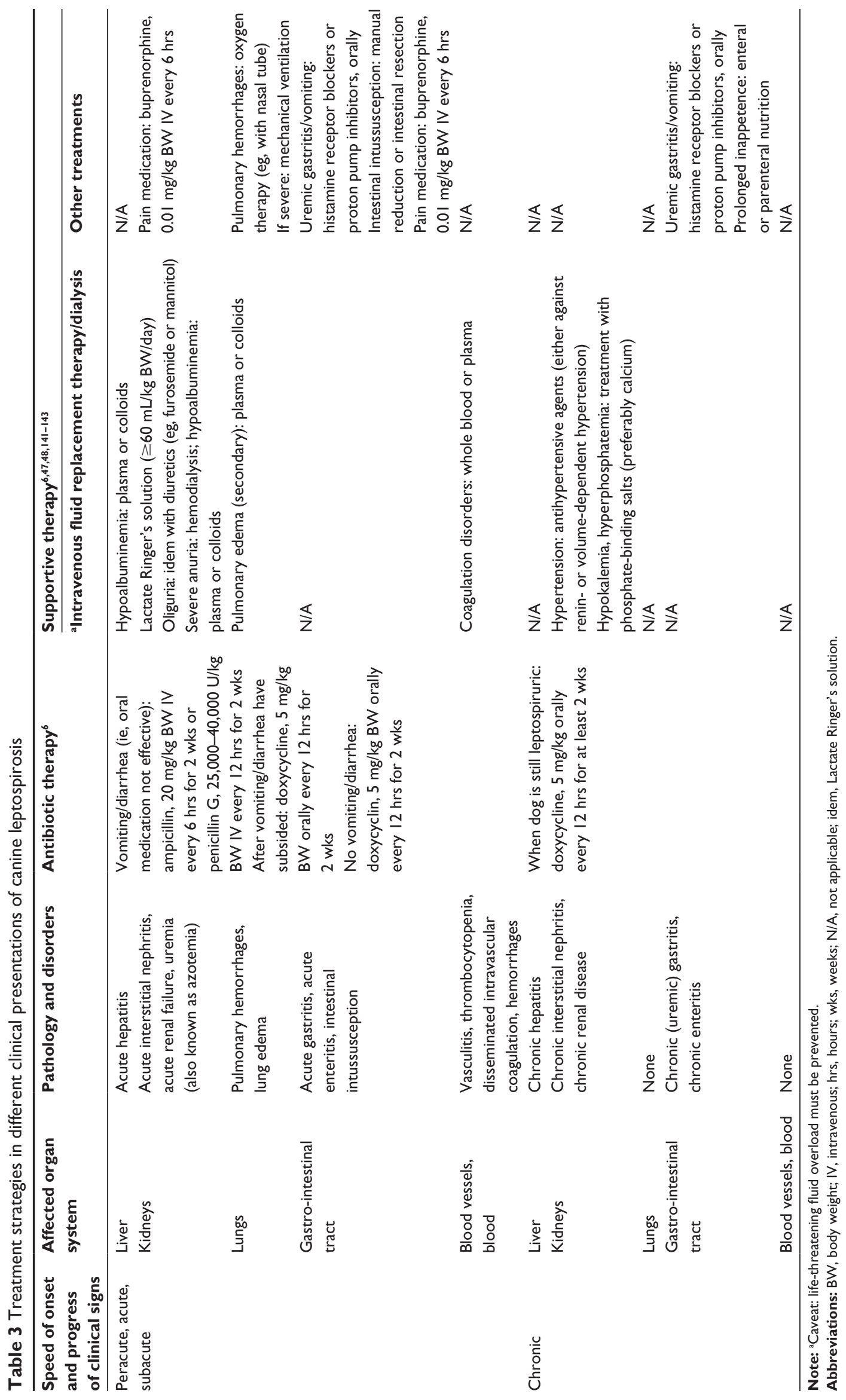


A specific drawback of leptospirosis bacterins that cannot be solved by an increase of the amount of protective antigen is the efficacy spectrum; protection is directed only against the vaccine serovars or closely related serovars. ${ }^{18,61}$ Evidence of cross-protection by bacterins or LPS preparations against serovars from different serogroups has only rarely been published, ${ }^{62}$ although cross-protection following recovery from infection was reported in the $1970 \mathrm{~s} .{ }^{61}$ The restricted efficacy spectrum of bacterins requires a good knowledge of the regional epidemiology, which can be reliably gained only by culture and identification of locally prevalent serovars. This implies that, where multiple serovars are predominant in dogs, multivalent vaccines for dogs are necessary. This topic will be discussed in the following "Newly emerging serovars and multivalent bacterins" section.

A complicating factor in assessment of the onset and duration of immunity induced with vaccines is the unreliability of the MAT as an indicator of protection. In several vaccination-challenge studies in dogs using experimental infection, no correlation was found between protection and the titer of agglutinating antibodies prior to challenge. ${ }^{58,63-67}$ In bacterin-vaccinated dogs, MAT titers in general show a rapidly declining pattern, but in various studies, dogs without detectable agglutinating antibodies have been demonstrated to be protected, even 12 months after the last vaccination. ${ }^{64,65}$ Therefore, the MAT is unsuitable to assess the onset or duration of immunity elicited by vaccination of dogs. As long as there is no alternative laboratory assay correlating with protection, leptospiral challenge of dogs, unfortunately, is necessary to determine the efficacy of vaccines. In vaccination studies with cattle, cell-mediated immunity has been detected for at least 4 months after completion of a two-dose vaccination regimen. ${ }^{68,69}$ To the authors' knowledge, since the work of Bey and Johnson in the $1980 \mathrm{~s},{ }^{70}$ who used a lymphocyte stimulation test to measure serovar-specific, cell-mediated responses in dogs vaccinated with several leptospiral vaccines, no cell-mediated immunity studies in dogs have been reported. Even when serovar-specific, cellmediated responses could be measured in vaccinated dogs, this type of assay would be less suitable than serological assays for routine efficacy testing by vaccine manufacturers, since blood or cells have to be tested immediately after sampling from the animals. Therefore, it is necessary to continue the search for an alternative serological response that does show some correlation with protection, and, as is necessary for vaccines containing more than one serovar, is serovar-specific. So far, however, for dogs only Leptospira genus-specific and no serovar-specific antibody ELISAs have been developed and validated for diagnostic purposes (see the "Laboratory diagnosis" section).

Studies of duration of immunity of leptospirosis bacterins in dogs, assessed by Leptospira spp. challenge, have been reported less frequently than onset of immunity studies, probably due to the higher costs of the former. Whereas a duration of immunity of less than 6 months after the primary course and 1 year after each annual re-vaccination was determined in a serological study in dogs, ${ }^{45}$ vaccination-challenge studies performed by vaccine manufacturers show that protective immunity elicited by commercial bacterins lasts approximately 12 months. ${ }^{64,66}$ In humans, agglutinating (anti-LPS) antibodies are predominantly, but not exclusively, IgM. However, this is not necessarily the case in animals, where IgG agglutinating antibodies are often produced. Indeed, in revaccination studies in dogs with a novel tetravalent bacterin (Klaasen, unpublished data, 2006), an anamnestic MAT serological response was observed, with at least a fourfold difference between titers done after annual revaccination and those after primary vaccination (Klaasen, unpublished data, 2006).

\section{Newly emerging serovars and multivalent bacterins}

As described in the Canine leptospirosis: epidemiology and clinical characteristics section, an increased prevalence of dogs seropositive for Leptospira spp. has been reported in various countries around the world (EM Broens, personal communication, 2015). ${ }^{22-24}$ Changes in the epidemiology of canine leptospirosis in North America have led to the inclusion of serovars Grippotyphosa and Pomona in bacterins available there. In Europe, serovars other than the two "classical" bivalent bacterin serovars, Canicola and Icterohaemorrhagiae, have been reported as emerging serovars, particularly serovars Grippotyphosa and Bratislava. ${ }^{71,72}$ In recent years, trivalent (serogroups Canicola, Icterohaemorrhagiae, and Grippotyphosa) and tetravalent vaccines (serogroups Canicola, Icterohaemorrhagiae, Grippotyphosa, and Australis) have been licensed in European countries. In Australia, commercial bacterins for dogs containing strains of serogroups Icterohaemorrhagiae and/or Australis have been on the market for some time. The US Department of Agriculture, responsible for licensing of new animal vaccines in USA and involved in research into infectious diseases in animals, published a Center for Veterinary Biologics (CVB) notice Requirements for Addition of Leptospira bratislava in Canine Bacterins ${ }^{73}$ describing "the minimum evidence required for inclusion of the L. bratislava antigen 
in licensed leptospira-containing bacterins". The reason for this requirement was the lack of evidence by isolation for serovar Bratislava as a significant pathogen of dogs in the US. Nevertheless, in several European countries, strains of serovar Bratislava have been isolated from dogs with nephritis or reproductive diseases. ${ }^{71}$ Serovar Bratislava is associated with clinical and subclinical leptospirosis in several animal species, including reproductive disease. ${ }^{74-77}$ Since cases of mild or latent forms of canine leptospirosis are frequently missed by veterinary practitioners, either because the dog owners do not visit their veterinarian or due to misdiagnosis, the chance of underdiagnosis of serovar Bratislava infections in dogs is relatively high.

As long as no novel efficacious and broadly protecting leptospirosis vaccines have been developed, multivalent bacterins such as the tetravalent vaccines in the US and Europe will aid in the battle against canine leptospirosis. Vaccination with these bacterins, however, will only result in significant reduction of clinical disease and spreading by infected dogs when the major serovars of a given region are included in the vaccine. This limitation causes several hurdles in vaccine development. Apart from the difficulties in identifying the most important local serovars, the second hurdle in developing multivalent bacterins is to overcome the risk of insufficient efficacy with higher numbers of serovars in one vaccine. Here again, the use of appropriate adjuvants can minimize this possible risk. However, in the US and Europe (and countries that follow the US or European guidelines), efficacy claims of newly licensed canine leptospirosis bacterins are based on vaccine-challenge studies in dogs, by demonstrating protection against the relevant regional serovars. Therefore, non-efficacious vaccines will not be licensed.

\section{Growth media for vaccines}

Up to the present time, all licensed canine leptospirosis vaccines have been chemically or physically inactivated whole bacterial cell vaccines (bacterins) or "purified" bacterial cell wall vaccines. Early experimental or commercial bacterins were prepared by inactivating leptospires cultivated in media containing rabbit serum. Due to the use of rabbit serum and the variability in rabbit serum batches, the manufacturing processes were inconsistent, bacterial harvest often insufficient, and the vaccines unsafe for the target animals because of the allergenic effects of the foreign serum proteins. Clearly, any serum used must be free of anti-leptospirosis antibodies. Later, "serum-free", semi-defined, albumin-containing media were developed in which polysorbate 80 (Tween 80 ) replaced the essential fatty acids that were supplied by the rabbit serum and that are required by the Leptospira spp. bacteria as the sole source of energy and carbon. ${ }^{42}$ These media (one of which is the Ellinghausen-McCullough-Johnson-Harris [EMJH] medium, named after Ellinghausen and McCullough and modified by Johnson and Harris) are still widely used by researchers and vaccine manufacturers, and contain essential vitamins, salts, and minerals, $0.125 \% \mathrm{v} / \mathrm{v}$ polysorbate 80 , and up to $1 \% \mathrm{w} / \mathrm{v}$ bovine serum albumin (BSA). ${ }^{42}$ As Leptospira spp. bacteria in vitro do not utilize protein, the main function of the albumin component of EMJH is considered to be the detoxification of the fatty acids provided by the polysorbate 80 in the culture medium by reversibly complexing them, while keeping them biologically available. There is batch variation in the ability of BSA to support growth of leptospires. The delipidation of BSA with chloroform/ methanol improves growth, ${ }^{42}$ but is not suitable for large-scale processes. During the 1960s and 1970s, scientists attempted to develop chemically defined media free of serum and/or albumin. These media did not gain wide acceptance by vaccine manufacturers because adaptation of the Leptospira spp. strains to the new medium was mostly required, and many strains could not be cultivated at all. Additionally, a method of detoxification of polysorbates using charcoal to enhance growth of leptospires in the absence of albumin, although feasible at lab scale, appeared not to be suitable for (largescale) manufacturing purposes, because the detoxification was not consistent, and the processes were time-consuming and expensive, and resulted in inadequate antigen yields. In 2006, a patent application ${ }^{78}$ was published by a manufacturer reporting a novel method to culture Leptospira spp. bacteria in a protein-free and fatty acid-free medium, whereby fatty acids were "fed" to the bacteria through continuous feeding of low amounts of untreated (non-detoxified) polysorbates.

\section{Risk of allergic reactions in small-breed dogs}

Adverse reactions frequently observed in canine vaccination are allergic reactions such as urticaria, pruritus, facial edema, weakness/depression, dyspnea, vomiting, diarrhea, and hypotension. In a study in the US ${ }^{79}$ using electronic records of 1,226,159 dogs, a vaccine-associated adverse event (VAAE) rate was recorded as 38.2/10,000 dogs. Young adult, small-breed, neutered dogs that received multiple vaccines per office visit were at greatest risk of a VAAE. In a random sample of 400 dogs in this study, predominant adverse reactions (observed within 3 days of vaccine administration) consisted of facial or periorbital edema (31\%), wheals or urticaria $(21 \%)$, generalized pruritus (15\%), and vomiting $(10 \%)$. 
A Japanese research group ${ }^{80}$ suggested that immediate-type allergic reactions in dogs after vaccination were induced by type I hypersensitivity mediated by IgE directed against vaccine components such as fetal calf serum (FCS), gelatin, and casein. In their subsequent study, ${ }^{81}$ they detected IgE reactivity against BSA and other unknown bovine serum components, and they recommended elimination of FCS, BSA, and stabilizer proteins from the live and inactivated components of canine vaccines. Day, ${ }^{82}$ however, concluded that although there have always been adverse reactions to vaccinations in dogs and cats, the prevalence of such reactions is extremely low. Nevertheless, in a more recent study in Japan ${ }^{83}$ with data from 57,300 dogs vaccinated with non-rabies combined vaccines, the VAAE rate was $62.7 / 10,000$ dogs, which is almost twice as high as the VAAE rate in USA study. The authors suggested that the overrepresentation of small breeds in Japan and the proposed higher risk of VAAEs in dogs of small breeds ( $\leq 10 \mathrm{~kg}$ body weight) may have contributed to the higher VAAE rate in comparison with other countries. Despite the generally accepted view that small-breed dogs may be at higher risk of VAEEs, there is no consensus of whether or not the currently licensed canine leptospirosis vaccines are safe enough for small-breed dogs. ${ }^{6}$ Although the exact cause(s) of adverse reactions in dogs after vaccination with one of the available commercial leptospirosis vaccines are yet to be identified, some vaccine manufacturers have introduced refinements of their production processes to reduce the content of potentially allergenic compounds..$^{84,85}$

\section{Potential for recombinant vaccines}

As outlined in the previous "Risk of allergic reactions in small-breed dogs" section, bacterin vaccines induce immunity that is restricted to serovars that are closely related through surface-exposed, agglutinating, LPS antigens. Immunity following natural infection is likewise generally accepted as being serovar, or at best serogroup, specific. Nevertheless, there is substantial evidence that cross-protective immunity can be stimulated and that it is mediated by proteins (reviewed by Adler ${ }^{61}$ ). Vaccines based upon conserved leptospiral proteins would offer significant advantages, including broad coverage, ease and consistency of production, and reduced cost. There is now a substantial literature on protection studies performed with a large range of recombinant proteins in laboratory animals, most commonly hamsters, guinea pigs, or gerbils. Unfortunately, almost all of the claims of protection do not withstand rigorous scrutiny and are therefore dubious. The most common problems are inappropriate statistical analyses, lack of reproducibility, the use of incorrect controls, and the use of inadequate challenge doses. ${ }^{61}$ The outer membrane protein LigA currently represents the most promising candidate antigen. However, there is evidence that it may not protect against some serovars; for example, clear protective homologous immunity in hamsters has been shown with serovar Copenhageni, while homologous LigA did not protect against Manilae or Canicola. ${ }^{61}$ The reasons for this disparity are unknown.

Alternative delivery methods such as adenovirus vector $\left(\text { lipL32) }{ }^{86} \text { and plasmid DNA (lipL32, flaB }\right)^{87,88}$ have been reported; however, the results do not withstand biological and statistical scrutiny, and these approaches have not been developed further. A recent study ${ }^{89}$ suggested that immunization with LipL32 reduced kidney invasion in hamsters, but notably, there was no protection from lethality, thus limiting the value of these results. Indeed, a recent re-evaluation indicated that LipL32, the main candidate in these and many other vaccine studies, is not exposed on the leptospiral surface. ${ }^{90}$

A further caveat is that vaccination studies cannot necessarily be extrapolated to different animal species. Proper vaccination and challenge experiments in the target animal species are the only valid criteria for assessment of vaccine efficacy. Therefore, there is no prospect of a recombinant vaccine for canine leptospirosis in the foreseeable future.

\section{Disclosure}

EK is an employee of, and BA has acted as an expert adviser to, Merck, Sharp and Dohme Animal Health. The authors report no other conflicts of interest in this work.

\section{References}

1. Adler B, de la Peña Moctezuma A. Leptospira and leptospirosis. Vet Microbiol. 2010;140(3):287-296.

2. Levett PN. Systematics of Leptospiraceae. Curr Top Microbiol Immunol. 2015;387:11-20.

3. Ellis WA. Animal leptospirosis. Curr Top Microbiol Immunol. 2015; 387:99-137.

4. Verma A, Stevenson B, Adler B. Leptospirosis in horses. Vet Microbiol. 2013;167:61-66.

5. Goldstein RE. Canine leptospirosis. Vet Clin North Am Small Anim Pract. 2010;40:1091-1101.

6. Sykes JE, Hartmann K, Lunn KF, Moore GE, Stoddard RA, Goldstein RE. 2010 ACVIM small animal consensus statement on leptospirosis: diagnosis, epidemiology, treatment, and prevention. J Vet Intern Med. 2011;25(1):1-13.

7. Feigin RD, Lobes LA Jr, Anderson D, Pickering L. Human leptospirosis from immunized dogs. Ann Intern Med. 1973;79(6):777-785.

8. Gay N, Soupé-Gilbert ME, Goarant C. Though not reservoirs, dogs might transmit Leptospira in New Caledonia. Int J Environ Res Public Health. 2014;11:4316-4325.

9. Greene CE, Sykes JE, Moore GE. Leptospirosis. In: Greene CE, editor. Infectious Diseases of the Dog and Cat. St Louis, Missouri: Elsevier; 2012:431-447.

10. Adler B. Leptospira and leptospirosis. Berlin, Heidelberg: Springer Verlag; 2015. 
11. Murray GL. The molecular basis of leptospiral pathogenesis. Curr Top Microbiol Immunol. 2015;387:139-185.

12. Adler B. Pathogenesis of leptospirosis: cellular and molecular aspects. Vet Microbiol. 2014;172:353-358.

13. Murray GL. The lipoprotein LipL32, an enigma of leptospiral biology. Vet Microbiol. 2013;162(2-4):305-314.

14. Adler B, Lo M, Seemann T, Murray GL. Pathogenesis of leptospirosis: the influence of genomics. Vet Microbiol. 2011;153(1-2):73-81.

15. Croda J, Figueira CP, Wunder EA Jr, et al. Targeted mutagenesis in pathogenic Leptospira species: disruption of the LigB gene does not affect virulence in animal models of leptospirosis. Infect Immun. 2008;76(12):5826-5833.

16. Murray GL, Srikram A, Hoke DE, et al. Major surface protein LipL32 is not required for either acute or chronic infection with Leptospira interrogans. Infect Immun. 2009;77(3):952-958.

17. Caimano MJ, Sivasankaran SK, Allard A, et al. A model system for studying the transcriptomic and physiological changes associated with mammalian host-adaptation by Leptospira interrogans serovar Copenhageni. PLoS Pathog. 2014;10(3):e1004004.

18. Levett PN. Leptospirosis. Clin Microbiol Rev. 2001;14(2):296-326.

19. Mussot D, La Scola B. Laboratory diagnosis of leptospirosis: a challenge. J Microbiol Immunol Infect. 2013;46:245-252.

20. Ellis WA, Thrusfield MV, Van den Broek AHM. Letters to the Editors. J Small Animal Pract. 1991;91(2):432.

21. Levett PN. Usefulness of serologic analysis as a predictor of the infecting serovar in patients with severe leptospirosis. Clin Infect Dis. 2003;36:447-452.

22. Prescott JF, McEwen B, Taylor J, Woods JP, Abrams-Ogg A, Wilcock B. Resurgence of leptospirosis in dogs in Ontario: recent findings. Can Vet J. 2002;43(12):955-961.

23. Moore GE, Guptill LF, Glickman NW, Caldanaro RJ, Aucoin D, Glickman LT. Canine leptospirosis, United States, 2002-2004. Emerg Infect Dis. 2006;12(3):501-503.

24. Major A, Schweighauser A, Francey T. Increasing incidence of canine leptospirosis in Switzerland. Int J Environ Res Public Health. 2014;11(7):7242-7260.

25. Scanziani E, Crippa L, Giusti AM, et al. Leptospira interrogans serovar sejroe infection in a group of laboratory dogs. Lab Anim. 1995;29(3):300-306.

26. Rühl-Fehlert CI, Brem S, Feller W, Kopp H, Meyer P, Rinke M. Clinical, microbiological and pathological observations in laboratory beagle dogs infected with leptospires of the serogroup Sejroe. Exp Toxicol Pathol. 2000;52:201-207.

27. Bishop L, Strandberg JD, Adams RJ, Brownstein DG, Patterson R. Chronic active hepatitis in dogs associated with leptospires. Am J Vet Res. 1979;40(6):839-844.

28. Adamus C, Buggin-Daubié M, Izembart A, et al. Chronic hepatitis associated with leptospiral infection in vaccinated beagles. J Comp Pathol. 1997;117(4):311-328.

29. Silva JJ, Dalston MO, Carvalho JE, Setúbal S, Oliveira JM, Pereira MM. Clinicopathological and immunohistochemical features of the severe pulmonary form of leptospirosis. Rev Soc Bras Med Trop. 2002;35(4): 395-359.

30. Tattevin P, Léveiller G, Flicoteaux R, et al. Respiratory manifestations of leptospirosis: a retrospective study. Lung. 2005;183(4):283-289.

31. Gouveia EL, Metcalfe J, de Carvalho AL, et al. Leptospirosis-associated severe pulmonary hemorrhagic syndrome, Salvador, Brazil. Emerg Infect Dis. 2008;14(3):505-508.

32. Rentko VT, Clark N, Ross LA, Schelling SH. Canine leptospirosis. A retrospective study of 17 cases. J Vet Intern Med. 1992;6(4): 235-244.

33. Birnbaum N, Barr SC, Center SA, Schermerhorn T, Randolph JF, Simpson KW. Naturally acquired leptospirosis in 36 dogs: serological and clinicopathological features. J Small Anim Pract. 1998;39(5): 231-236.

34. Gendron K, Christe A, Walter S, et al. Serial CT features of pulmonary leptospirosis in 10 dogs. Vet Rec. 2014;174(7):169.
35. Baumann D, Flückiger M. Radiographic findings in the thorax of dogs with leptospiral infection. Vet Radiol Ultrasound. 2001;42(4): 305-307.

36. Kohn B, Steinicke K, Arndt G, et al. Pulmonary abnormalities in dogs with leptospirosis. J Vet Intern Med. 2010;24:1277-1282.

37. Klopfleisch R, Kohn B, Plog S, et al. An emerging pulmonary haemorrhagic syndrome in dogs: similar to the human leptospiral pulmonary haemorrhagic syndrome? Vet Med Int. 2010;2010:928541.

38. Hartman EG, Van den Ingh TS, Rothuizen J. Clinical, pathological and serological features of spontaneous canine leptospirosis. An evaluation of the IgM- and IgG-specific ELISA. Vet Immunol Immunopathol. 1986;13:261-271.

39. Schweighauser A, Burgener IA, Gaschen F, et al. Small intestinal intussusception in five dogs with acute renal failure and suspected leptospirosis (L. australis). J Vet Emerg Crit Care. 2009;19(4):363-368.

40. Schulz BS, Seybold N, Adamik KN, Ludwig E, Hartmann K. Ileocolic intestinal intussusception in a dog with leptospirosis. Tierarztl Prax Ausg K Kleintiere Heimtiere. 2010;38(6):403-405.

41. Rissi D, Brown CA. Diagnostic features in 10 naturally occurring cases of acute fatal canine leptospirosis. J Vet Diagn Invest. 2014;26(6):799-804.

42. Cameron CE. Leptospiral structure, physiology, and metabolism. Curr Top Microbiol Immunol. 2015;387:21-41.

43. Picardeau M. Diagnosis and epidemiology of leptospirosis. Med Mal Infect. 2013;43:1-9.

44. Perez J, Goarant C. Rapid Leptospira identification by direct sequencing of the diagnostic PCR products in New Caledonia. BMC Microbiol. 2010;10:325.

45. Hartman EG. An IgM- and IgG-specific enzyme-linked immunosorbent assay (ELISA) to detect anti-leptospiral immunoglobulins in dogs. Zentralbl Bakteriol Mikrobiol Hyg A. 1984;257:508-510.

46. Abdoel TH, Houwers DJ, van Dongen AM, et al. Rapid test for the serodiagnosis of acute canine leptospirosis. Vet Microbiol. 2011; 150(1-2):211-213.

47. Wohl J. Canine leptospirosis. Compend Contin Educ Pract Vet. 1996; 18(11):1215-1224.

48. Adin CA, Cowgill LD. Treatment and outcome of dogs with leptospirosis: 36 cases (1990-1998). J Am Vet Med Assoc. 2000;216(3):371-375.

49. Ido Y, Hoki R, Ito H, Wani H. The prophylaxis of Weil's disease (Spirochaetosis icterohaemorrhagica). J Exp Med. 1916;24:471-483.

50. Bey RF, Johnson RC. Current status of leptospiral vaccines. Prog Vet Microbiol Immunol. 1986;2:175-197.

51. Fort Dodge Animal Health unveils Leptospira vaccine [webpage on the Internet]. Lenexa, KS: Advanstar Communications, Veterinary Group. Available from: http://veterinarynews.dvm360.com/fort-dodge-animalhealth-unveils-leptospira-vaccine. Accessed February 1, 2015.

52. Bey RF, Auran NE, Johnson RC. Immunogenicity of whole cell and outer envelope vaccines in hamsters. Infect Immun. 1974;10:1051-1056.

53. Takashima I, Yanagawa R. Immunizing effects of structural components of Leptospira icterohaemorrhagiae. Zentralbl Bakteriol Orig A. 1975;233(1):93-98.

54. Reif JS, Marshak RR. Editorial: Leptospirosis: a contemporary zoonosis. Ann Intern Med. 1973;79(6):893-894.

55. Meyer KF, Brunner KT. Chemotherapy and immunity in Leptospira canicola and L. icterohaemorrhagiae infections. Acta Tropica. 1950; $7: 1-6$.

56. Huhn RG, Baldwin CD, Cardella MA. Immunity to leptospirosis: bacterins in dogs and hamsters. Am J Vet Res. 1975;36(1):71-74.

57. Marshall V. Efficacy of Leptospira vaccine. J Am Vet Med Assoc. 1983;183(1):12,34.

58. André-Fontaine G, Branger C, Gray AW, Klaasen HL. Comparison of the efficacy of three commercial bacterins in preventing canine leptospirosis. Vet Rec. 2003;153:165-169.

59. European Medicines Agency. Veterinary Regulatory. ProductInformation Requirements. Available from: http://www.ema. europa.eu/ema/index.jsp?curl=pages/regulation/general/general_ content_000204.jsp\&mid=WC0b01ac058002d4ee. Accessed May 22, 2015. 
60. Code of Federal Regulations Title 9, Chapter I, Subchapter E, Part 102, §102.5: U.S. Veterinary Biological Product License. Available from: http://www.ecfr.gov/cgi-bin/text-idx?SID=838dbafb69eff2574b8aa7f $800 \mathrm{~b} 9 \mathrm{~d} 61 \mathrm{c} \& \mathrm{mc}=$ true \&node=se9.1.102_15\&rgn=div8. Accessed May 22, 2015.

61. Adler B. Vaccines against leptospirosis. Curr Top Microbiol Immunol. 2015;387:251-272.

62. Sonrier C, Branger C, Michel V, Ruvoën-Clouet N, Ganière JP, AndréFontaine G. Evidence of cross-protection within Leptospira interrogans in an experimental model. Vaccine. 2000;19:86-94.

63. Broughton ES, Scarnell J. Prevention of renal carriage of leptospirosis in dogs by vaccination. Vet Rec. 1985;117:307-311.

64. Klaasen HL, Molkenboer MJCH, Vrijenhoek MP, Kaashoek MJ. Duration of immunity in dogs vaccinated against leptospirosis with a bivalent inactivated vaccine. Vet Microbiol. 2003;95(1-2):121-132.

65. Schreiber P, Martin V, Najbar W, Sanquer A, Gueguen S, Lebreux B. Prevention of renal infection and urinary shedding in dogs by a Leptospira vaccination. Vet Microbiol. 2005;108(1-2):113-118.

66. Minke JM, Bey R, Tronel JP, et al. Onset and duration of protective immunity against clinical disease and renal carriage in dogs provided by a bi-valent inactivated leptospirosis vaccine. Vet Microbiol. 2009;137(1-2):137-145.

67. Klaasen HL, van der Veen M, Molkenboer MJ, Sutton D. A novel tetravalent Leptospira bacterin protects against infection and shedding following challenge in dogs. Vet Rec. 2013;172(7):181.

68. Brown RA, Blumerman S, Gay C, Bolin C, Duby R, Baldwin CL. Comparison of three different leptospiral vaccines for induction of a type 1 immune response to Leptospira borgpetersenii serovar Hardjo. Vaccine. 2003;21(27-30):4448-4458.

69. Naiman BM, Alt D, Bolin CA, Zuerner R, Baldwin CL. Protective killed Leptospira borgpetersenii vaccine induces potent Th1 immunity comprising responses by $\mathrm{CD} 4$ and gammadelta $\mathrm{T}$ lymphocytes. Infect Immun. 2001;69(12):7550-7558.

70. Bey RF, Johnson RC. Immunogenicity and humoral and cell-mediated immune responses to leptospiral whole cell, outer envelope, and protoplasmic cylinder vaccines in hamsters and dogs. Am J Vet Res. 1982;43(5):835-840.

71. Ellis WA. Control of canine leptospirosis in Europe: time for a change? Vet Rec. 2010;167(16):602-605.

72. Renaud C, Andrews S, Djelouadji Z, et al. Prevalence of the Leptospira serovars bratislava, grippotyphosa, mozdok and pomona in French dogs. Vet J. 2013;196(1):126-127.

73. United States Department of Agriculture. Center for Veterinary Biologics Notice No 05-06: Requirements for Addition of Leptospira bratislava in Canine Bacterins. Aimes, IA: United Sates Department of Agriculture; 2005. Available from: http://www.aphis.usda.gov/animal_health/ vet_biologics/publications/notice_05_06.pdf. Accessed February 1, 2015.

74. Bolin CA, Cassells JA. Isolation of Leptospira interrogans serovar bratislava from stillborn and weak pigs in Iowa. J Am Vet Med Assoc. 1990;196:1601-1604.

75. Graham EM, Taylor DJ. Bacterial reproductive pathogens of cats and dogs. Vet Clin North Am Small Anim Pract. 2012;42:561-582.

76. Hamond C, Pinna A, Martins G, Lilenbaum W. The role of leptospirosis in reproductive disorders in horses. Trop Anim Health Prod. 2014;46:1-10.

77. Nielsen JN, Cochran GK, Cassells JA, Hanson LE. Leptospira interrogans serovar bratislava infection in two dogs. JAm Vet Med Assoc. 1991;199(3):351-352.

78. Pierre N, Carboulec Y, inventors; Merial Ltd, assignee. Leptospirosis culture process. United States Patent US 8642316 B2. April 20, 2006.

79. Moore GE, Guptill LF, Ward MP, et al. Adverse events diagnosed within three days of vaccine administration in dogs. $\mathrm{J} \mathrm{Am} \mathrm{Vet} \mathrm{Med} \mathrm{Assoc.}$ 2005;227(7):1102-1108.

80. Ohmori K, Masuda $\mathrm{K}$, Maeda $\mathrm{S}$, et al. IgE reactivity to vaccine components in dogs that developed immediate-type allergic reactions after vaccination. Vet Immunol Immunopathol. 2005;104(3-4):249-256.
81. Ohmori K, Masuda K, DeBoer DJ, Sakaguchi M, Tsujimoto H. Immunoblot analysis for IgE-reactive components of fetal calf serum in dogs that developed allergic reactions after non-rabies vaccination. Vet Immunol Immunopathol. 2007;115(1-2):166-171.

82. Day MJ. Vaccine side effects: fact and fiction. Vet Microbiol. 2006; 117:51-58.

83. Miyaji K, Suzuki A, Shimakura H, et al. Large-scale survey of adverse reactions to canine non-rabies combined vaccines in Japan. Vet Immunol Immunopathol. 2012;145:447-452.

84. Klaasen E, Adriaanse HMA, van der Veen M, et al. Reduced risk of allergic reactions in dogs to a new tetravalent canine leptospirosis vaccine. Presented at: Voorjaarsdagen 46th European Veterinary Conference; 2013; Amsterdam, the Netherlands.

85. Pfizer Animal Health [webpage on the Internet]. Product Guide - Pfizer Family of Vaccines, New Jersey, USA. Available from: https://www. zoetisus.com/_locale-assets/mcm-portal-assets/my-resources/specieslanding-page-pdf/dog/canine_vaccines.pdf. Accessed February 1, 2015.

86. Branger C, Sonrier C, Chatrenet B, et al. Identification of the hemolysisassociated protein 1 as a cross-protective immunogen of Leptospira interrogans by adenovirus-mediated vaccination. Infect Immun. 2001;69(11):6831-6838.

87. Branger C, Chatrenet B, Gauvrit A, et al. Protection against Leptospira interrogans sensu lato challenge by DNA immunization with the gene encoding hemolysin-associated protein 1. Infect Immun. 2005;73(7):4062-4069.

88. Dai B, You Z, Chen Z, Yan H, Fang Z. Protection against leptospirosis by immunization with plasmid DNA encoding $33 \mathrm{kDa}$ endoflagellin of L. interrogans serovar lai. Chin Med Sci J. 2000;15(1):14-19.

89. Humphryes PC, Weeks ME, AbuOun M, Thomson G, Núñez A, Coldham NG. Vaccination with leptospiral outer membrane lipoprotein LipL32 reduces kidney invasion of Leptospira interrogans serovar canicola in hamsters. Clin Vaccine Immunol. 2014;21(4): $546-551$.

90. Pinne M, Haake DA. LipL32 is a subsurface lipoprotein of Leptospira interrogans: presentation of new data and reevaluation of previous studies. PLoS One. 2013;8(1):e51025.

91. Michna S, Ellis W. Incidence of antibodies for leptospirosis in dogs in Glasgow, and a comparison of the conventional (Schuffner's) and rapid microscopical agglutination (RMAT) tests. Vet Rec. 1973;93(24): 633-634.

92. Fuchs GHP, Hartmann H. Über das Vorkommen von Leptospireninfektionen bei Dienst und Gebrauchshunderassen im Bezirk Dresden [Occurrence of Leptospira infections among service and working breeds of dogs in the Dresden region]. Arch Exp Veterinärmed. 1974;28(6): 869-877. German.

93. Timoney JF, Sheahan BJ, Timoney PJ. Leptospira and infectious canine hepatitis (ICH) virus antibodies and nephritis in Dublin dogs. Vet Rec. 1974;94(14):316-319.

94. Brem S, Staak C, Schönberg A, Kopp H, Meyer P. Investigations of leptospiral serology in dogs. Tierarztliche Umschau. 1999;54(2): $83-87$.

95. Scanziani E, Origgi F, Giusti AM, et al. Serological survey of leptospiral infection in kennelled dogs in Italy. J Small Anim Pract. 2002; 43(4):154-157.

96. Burriel AR, Dalley C, Woodward MJ. Prevalence of Leptospira species among farmed and domestic animals in Greece. Vet Rec. 2003;153(5):146-148.

97. Geier-Dömling D, Heil-Franke G, Müller E. The prevalence of serum antibodies against some Leptospira in dogs. Kleintierpraxis. 2003;48(12):755-758.

98. André-Fontaine G. Canine leptospirosis - do we have a problem? Vet Microbiol. 2006;117(1):19-24.

99. Geisen V, Stengel C, Hartmann K. Epidemiologische Situation der Leptospirose beim Hund in Südddeutschland [Epidemiological situation of leptospirosis in dogs in South Germany]. Tierärztl Prax [Vet pract]. 2008;36(K):329-336. German. 
100. Gerlach T, Stephan I. Epidemiologische Situation der kaninen Leptospirose in Norddeutschland in den Jahren 2003-2006 [Epidemiological situation of canine leptospirosis in North Germany in the period 2003-2006. A retrospective study]. Eine Retrospektive Studie. Tierärztl Prax. [Vet pract] 2007;35(K):421-429. German.

101. Hazart G, Hugonnard M, Kodjo A, et al. La leptospirose canine en France: étude rétrospective de 37 cas [Canine leptospirosis in France: A retrospective study of 37 cases]. Prat Med Chir Anim Cie. 2010;45:59-64. French.

102. Houwers DJ, Goris MG, Abdoel T, et al. Agglutinating antibodies against pathogenic Leptospira in healthy dogs and horses indicate common exposure and regular occurrence of subclinical infections. Vet Microbiol. 2011;148(2-4):449-451.

103. Barmettler R, Schweighauser A, Bigler S, Grooters AM, Francey T. Assessment of exposure to Leptospira serovars in veterinary staff and dog owners in contact with infected dogs. J Am Vet Med Assoc. 2011;238(2):183-188.

104. Mayer-Scholl A, Luge E, Draeger A, Nöckler K, Kohn B. Distribution of Leptospira serogroups in dogs from Berlin, Germany. Vector Borne Zoonotic Dis. 2013;13(3):200-202.

105. Ayral FC, Bicout DJ, Pereira H, Artois M, Kodjo A. Distribution of Leptospira serogroups in cattle herds and dogs in France. Am J Trop Med Hyg. 2014;91(4):756-759.

106. Kingscote B, Tittiger F. Serological survey of dogs from Toronto for leptospiral antibodies. Can Vet J. 1976;17(7):192-193.

107. Thiermann AB. Canine leptospirosis in Detroit. Am J Vet Res. 1980;41(10):1659-1661.

108. Prescott JF, Ferrier RL, Nicholson VM, Johnston KM, Hoff B. Is canine leptospirosis underdiagnosed in southern Ontario? A case report and serological survey. Can Vet J. 1991;32:481-486.

109. Boutilier P, Carr A, Schulman RL. Leptospirosis in dogs: a serologic survey and case series 1996 to 2001. Vet Ther. 2003;4(4):387-396.

110. Harkin KR, Roshto YM, Sullivan JT, Purvis TJ, Chengappa MM. Comparison of polymerase chain reaction assay, bacteriologic culture, and serologic testing in assessment of prevalence of urinary shedding of leptospires in dogs. J Am Vet Med Assoc. 2003;222(9): 1230-1233.

111. Ward MP, Guptill LF, Prahl A, Wu CC. Serovar-specific prevalence and risk factors for leptospirosis among dogs: 90 cases (1997-2002). $J$ Am Vet Med Assoc. 2004;224(12):1958-1963.

112. Stokes JE, Kaneene JB, Schall WD, et al. Prevalence of serum antibodies against six Leptospira serovars in healthy dogs. J Am Vet Med Assoc. 2007;230(11):1657-1664.

113. Ghneim GS, Viers JH, Chomel BB, Kass PH, Descollonges DA, Johnson ML. Use of a case-control study and geographic information systems to determine environmental and demographic risk factors for canine leptospirosis. Vet Res. 2007;38(1):37-50.

114. Gautam R, Guptill LF, Wu CC, Potter A, Moore GE. Spatial and spatiotemporal clustering of overall and serovar-specific Leptospira microscopic agglutination test (MAT) seropositivity among dogs in the United States from 2000 through 2007. Prev Vet Med. 2010;96(1-2): 122-131.

115. Myers DM. Leptospiral antibodies in stray dogs of Moreno, Province of Buenos Aires, Argentina. Rev Argent Microbiol. 1980;12(1):18-22.

116. Pineda M, López J, García M. Serological survey of canine leptospirosis in Chillán, Chile. Arch Med Vet. 1996;28(1):59-66.

117. Weekes CC, Everard CO, Levett PN. Seroepidemiology of canine leptospirosis on the island of Barbados. Vet Microbiol. 1997;57(2-3): 215-222.

118. Petrakovsky J, Bianchi A, Fisun H, Nájera-Aguilar P, Pereira MM. Animal leptospirosis in Latin America and the Caribbean countries: reported outbreaks and literature review (2002-2014). Int J Environ Res Public Health. 2014;11(10):10770-10789.

119. Watson AD, Wannan JS, Porges WL, Testoni FJ. Leptospiral agglutinins in dogs in Sydney. Aust Vet J. 1976;52(9):425-426.

120. Collings DF. Leptospira interrogans infection in domestic and wild animals in Fiji. $N Z$ Vet $J .1984 ; 32(2): 21-24$.

121. Simms JR. Animal leptospirosis in the Federated States of Micronesia. Pacific Health Dialog. 1998;5(1):30-37.
122. O'Keefe JS, Jenner JA, Sandifer NC, Antony A, Williamson NB. A serosurvey for antibodies to Leptospira in dogs in the lower North Island of New Zealand. $N$ Z Vet J. 2002;50(1):23-25.

123. Lai CJ, Liu CC, Ho D, Pan MJ. Seroprevalence of Leptospira infection among stray dogs at Northern Taiwan. Taiwan Vet J. 2005; 31(1):1-8.

124. Meeyam T, Tablerk P, Petchanok B, Pichpol D, Padungtod P. Seroprevalence and risk factors associated with leptospirosis in dogs. Southeast Asian J Trop Med Public Health. 2006;37(1):148-153.

125. Zwijnenberg RJ, Smythe LD, Symonds, MI, Dohnt MF, Toribio JA. Cross-sectional study of canine leptospirosis in animal shelter populations in mainland Australia. Aust Vet J. 2008;86(8):317-323.

126. Iwamoto E, Wada Y, Fujisaki Y, et al. Nationwide survey of Leptospira antibodies in dogs in Japan: Results from microscopic agglutination test and enzyme-linked immunosorbent assay. J Vet Med Sci. 2009;71(9):1191-1199.

127. Koizumi N, Muto MM, Akachi S, et al. Molecular and serological investigation of Leptospira and leptospirosis in dogs in Japan. J Med Microbiol. 2013;62(Pt 4):630-636.

128. Patil D, Dahake R, Roy S, Mukherjee S, Chowdhary A, Deshmukh R. Prevalence of leptospirosis among dogs and rodents and their possible role in human leptospirosis from Mumbai, India. Indian J Med Microbiol. 2014;32(1):64-67.

129. Siam MA, Karim AM, Hamed OM, Zakaria A. The possible role of stray dogs and cats in the epidemiology of some bacterial human pathogens in Egypt. Zentralbl Veterinarmed B. 1973;20(6):409-414.

130. Aslantaş O, Ozdemir V, Kiliç S, Babür C. Seroepidemiology of leptospirosis, toxoplasmosis and leishmaniasis among dogs in Ankara, Turkey. Vet Parasitol. 2005;129:187-191.

131. Okewole EA, Ayoola MO. Seroprevalence of leptospiral serovars other than Canicola and Icterohaemorrhagiae in dogs in the Southwestern Nigeria. Veterinarski Arhiv. 2009;79(1):87-96.

132. Roach JM, Van Vuuren M, Picard JA. A serological survey of antibodies to Leptospira species in dogs in South Africa. J S Afr Vet Assoc. 2010;81(3):156-159.

133. Dhliwayo S, Matope G, Marabini L, Dutlow K, Pfukenyi DM. Seroprevalence of leptospirosis in dogs in urban Harare and selected rural communities in Zimbabwe. Onderstepoort $J$ Vet Res. 2012;79(1):E1-E6.

134. Millán J, Chirife AD, Kalema-Zikusoka G, et al. Serosurvey of dogs for human, livestock, and wildlife pathogens, Uganda. 2013;19(4). Emerg Infect Dis. 2013;19(4):680-682.

135. Faine $\mathrm{S}$. Clinical leptospirosis in humans, and clinical leptospirosis in animals. Leptospira and Leptospirosis. Boca Raton: CRC Press; 1994.

136. Langston CE, Heuter KJ. Leptospirosis; a re-emerging zoonotic disease. Vet Clin North Am Small Anim Pract. 2003;33:791-807.

137. Prescott J. Canine leptospirosis in Canada: a veterinarian's perspective. CMAJ. 2008;178(4):397-398.

138. Geisen V, Stengel C, Brem S, Müller W, Greene C, Hartmann K. Canine leptospirosis infections - clinical signs and outcome with different suspected Leptospira serogroups (42 cases). J Small Anim Pract. 2007;48(6):324-328.

139. Miller R, Ross S, Sullivan N, Perkins NR. Clinical and epidemiological features of canine leptospirosis in North Queensland. Aust Vet $J$. 2007;85(1-2):13-19.

140. van de Maele I, Claus A, Haesebrouck F, Daminet S. Leptospirosis in dogs: a review with emphasis on clinical aspects. Vet Rec. 2008; 163(14):409-413.

141. Levitan DM. Did you consider leptospirosis? Acute renal failure with or without jaundice can have this zoonotic etiology. Vet Forum. 1998:42-50.

142. Ross L. Acute kidney injury in dogs and cats. Vet Clin North Am Small Anim Pract. 2011;41:1-14.

143. Syme H. Hypertension in small animal kidney disease. Vet Clin North Am Small Anim Pract. 2011;41:63-89. 


\section{Publish your work in this journal}

Veterinary Medicine: Research and Reports is an international, Visit http://www.dovepress.com/testimonials.php to read real quotes peer-reviewed, open access journal publishing original research, case reports, editorials, reviews and commentaries on all areas of veterinary medicine. The manuscript management system is completely online and includes a very quick and fair peer-review system.

Submit your manuscript here: http://www.dovepress.com/veterinary-medicine-research-and-reports-journal 